\title{
Anti-IGLON5 disease
}

\section{A new case without neuropathologic evidence of brainstem tauopathy}

Maria Elena Erro, MD, PhD, Lidia Sabater, MD, PhD, Laura Martínez, MD, María Herrera, MD,
Aiora Ostolaza, MD, Iñaki García de Gurtubay, MD, PhD, Teresa Tuñón, MD, PhD, Francesc Graus, MD, PhD,
and Ellen Gelpi, MD, PhD

Neurol Neuroimmunol Neuroinflamm 2020;7:e651. doi:10.1212/NXI.0000000000000651

\section{Abstract}

\section{Objective}

To describe the neuropathologic features and the molecular data of phosphorylated tau (pTau) in a new case of anti-IgLON5 disease.

\section{Methods}

Review of clinical data, postmortem neuropathologic examination. Biochemical analyses of pTau were performed in brain samples from the present case and from a previously described patient with anti-IgLON5 with the characteristic brainstem tauopathy.

\section{Results}

The patient was a 71-year-old man with a clinical syndrome consisting of sleep disturbance and bulbar symptoms. IgLON5 antibodies of predominant IgG4 subtype were detected in serum and CSF. He carried the HLA DRB1*10:01-DQB1*05:01 haplotype. Despite treatment with IV immunoglobulins, he unexpectedly died during sleep 2 years after disease onset. Histology showed neurofibrillary pathology and $\beta$-amyloid deposits consistent with Alzheimer disease (AD) of intermediate severity. pTau deposits were absent in the brainstem. There were few perivascular $\mathrm{CD}^{+} \mathrm{T}$-cell infiltrates in the posterior hypothalamus, amygdala, and brainstem with microglial activation. The pTau immunoblot showed a pattern of bands consistent with $\mathrm{AD}$, which was different from that observed in the patient with anti-IgLON5 with brainstem tauopathy who presented a differential band around $56 \mathrm{KDa}$.

\section{Conclusion}

The absence of pTau deposits in the brainstem of the present patient suggests that the tauopathy of patients with anti-IgLON5 disease may be a late, secondary event. The antiIgLON5 brainstem tauopathy has a specific molecular signature different from primary tauopathies. pTau deposits restricted to the hippocampus/limbic regions of patients with antiIgLON5 may represent an age-related comorbidity.

\author{
Correspondence \\ Dr. Erro \\ elena.erro.aguirre@cfnavarra.es
}




\section{Glossary}

$\mathbf{A D}=$ Alzheimer disease $;$ PART $=$ primary age-related tauopathy; $\mathbf{p}$ Tau $=$ phosphorylated tau.

Anti-IgLON5 disease is a recently characterized disorder associated with antibodies against the neuronal cell-adhesion protein IgLON5. Main clinical features include a sleep disorder with non-rapid eye movement and rapid eye movement parasomnias, obstructive sleep apnea, and stridor, along with oculomotor and bulbar symptoms, and gait instability. ${ }^{1}$ Initial neuropathologic findings disclosed a novel neuronal 3- and 4-repeat tauopathy with preferential involvement of the brainstem tegmentum. ${ }^{2}$ Since the initial descriptions, the brain biopsy in 2 cases and the autopsy in another have not shown these particular tauopathy. ${ }^{3-5}$ We present the neuropathologic features and the molecular data of phosphorylated tau (pTau) in a new anti-IgLON5 patient.

\section{Methods}

\section{Neuropathology}

Immediately after removal of the brain, fresh samples from the frontal cortex, hippocampus, and brainstem were snap frozen and stored at $-80^{\circ} \mathrm{C}$ for further biochemical studies. Selected formalin-fixed and paraffin-embedded samples of the brain including all lobes, basal ganglia, hippocampus, brainstem, cerebellum, and spinal cord were cut at 4- $\mu \mathrm{m}$-thick sections and stained with hematoxylin and eosin or processed for immunohistochemistry as previously described. ${ }^{1}$

\section{Immunoblot of pTau}

Sarkosyl-insoluble fraction proteins were prepared from frozen samples of the hippocampus, hypothalamus, and midbrain periaqueductal gray matter of the patient, the brainstem of a previously reported anti-IgLON5 case (patient 7 described in Lancet Neurology $)^{1}$ fulfilling the postmortem diagnostic criteria of IgLON5 tauopathy, and the prefrontal cortex of a patient with Alzheimer disease $(\mathrm{AD})$. Briefly, samples were homogenized and centrifuged twice at 20,000g. The supernatants were combined and incubated with $1 \% \mathrm{~N}$-lauroylsarcosine (wt/vol) for 1 hour and centrifuged at $100,000 \mathrm{~g}$ to get the sarkosyl-insoluble pellets that were subjected to immunoblot.

Immunoblots were run following denaturing standard procedures, proteins were transferred to a nitrocellulose membrane, and strips were incubated with anti-pTau (AT8, Thermo-Scientific, Rockford), anti-3Rtau (Merck-Millipore, Billerica, MA), and anti-4Rtau (Cosmo Bio, Tokyo, Japan) antibodies, appropriate secondary antibodies, and the results were visualized by enhanced chemiluminescence.

\section{Results}

\section{Case report}

A 71- year-old man began to present mild forgetfulness in September 2016, followed by gait disturbance, weight loss, and dysphagia. In the previous 2 years, he had had insomnia, and he woke up confused and presented enuresis. On neurologic examination, cognition was normal. There was dysarthria, palpebral ptosis, velopalatine and oromandibular dyskinetic movements, spontaneous myoclonus and postural tremor in upper limbs. He fell backward on pull test, and his walking was slow, with limited arm swing. Cranial magnetic resonance, CSF analysis, EEG, and electromyogram were normal. Polysomnography showed very poorly differentiated sleep graph elements. In addition, desaturations and central hypoventilations were identified. Videoregistry showed abnormal pseudo-rhythmic movements at $0.7 \mathrm{~Hz}$, cramps, and complex movement automatisms during rapid eye movement and non-rapid eye movement phases. IgLON5 antibodies were detected in serum and CSF, and they were predominantly IgG4 subclass. Other autoantibodies against neuronal surface antigens were negative. The patient carried the HLA DRB1*10:01- DQB1*05:01 haplotype. Treatment with IV immunoglobulins did not improve the symptoms. The patient unexpectedly died during sleep, 24 months after the first symptoms began.

\section{Neuropathology}

Unfixed brain weight was 1,200 g. Gross examination was unremarkable. Histology showed a moderate pTau neurofibrillary pathology (AT8 immunohistochemistry) accentuated in temporomedial regions with frequent dystrophic neurites around amyloid plaques and few tangles and neuropil threads in cortical areas. Neurofibrillary pathology was more prominent in the amygdala, entorhinal and transentorhinal region, subiculum, and to a mild extent in the CA1 sector of the hippocampus and the temporo-occipital cortex (figure 1, B and C). There was mild involvement of the anterior thalamic and posterior hypothalamic nuclei. In the brainstem, obvious neuronal loss was absent. There were scarce neurofibrillary tangles and neuropil threads in the periaqueductal gray matter and raphe nuclei (figure 1D), with no involvement of the substantia nigra, pontine base, medulla oblongata or cerebellum, and absent pTau deposits in brainstem tegmentum (figure 1, E and F). A moderate density of diffuse and compact (mature/ cored) $A \beta$ deposits was detected in cortical areas, limbic system, basal ganglia, superior colliculi, and periaqueductal gray (figure 1A) along with mild amyloid angiopathy, consistent with $\mathrm{AD}$ neuropathologic changes of intermediate severity (Braak neurofibrillary stage III, Thal amyloid phase 4, CERAD moderate neuritic plaque score [A3, B2, C2]). No alpha-synuclein or pTDP43 protein aggregates were identified. There were few perivascular and parenchymal lymphocytic infiltrates in the posterior hypothalamus, amygdala, hippocampus, and brainstem regions, mainly composed of $\mathrm{CD}^{+} \mathrm{T}$ cells (figure 1,G-I) and an increase of activated HLA-DR+ microglia (figure $1 G$ ). 


\section{pTau immunoblot}

The present anti-IgLON5 case showed sarkosyl-insoluble pTau bands consisting of 3R and 4R isoforms with the same pattern observed in the hippocampus of a patient with $\mathrm{AD}$. In contrast, the immunoblot of the brainstem of a previously described patient with anti-IgLON5 with extensive brainstem pathology presented a different pattern of $\mathrm{pTau}$ with a differential band around $56 \mathrm{KDa}$ (figure 2).

\section{Discussion}

The neuronal, brainstem-predominant tauopathy described in the initial series of anti-IgLON5 disease was not identified here, but a moderate $\mathrm{AD}$-related pathology and a mild T-cell dominated inflammatory infiltration in the hypothalamus, hippocampus, and brainstem. This was unexpected, as the patient displayed a very suggestive clinical syndrome, IgLON5 antibodies in serum and CSF, and the characteristic HLA DRB1*10:01-DQB1*05:01 haplotype, which is present in $\sim 60 \%$ of patients with antiIgLON5 disease. ${ }^{6}$ In addition, the pTau immunoblot of the hippocampus was also in accordance with a pattern of $\mathrm{AD}$ pathology, whereas it was different from that of the previously described patient with anti-IgLON5 with the predominant brainstem tauopathy that showed a novel pattern of $\mathrm{pTau}$ bands not described in other primary tauopathies. $^{7}$

Figure 1 Neuropathologic findings of the reported patient
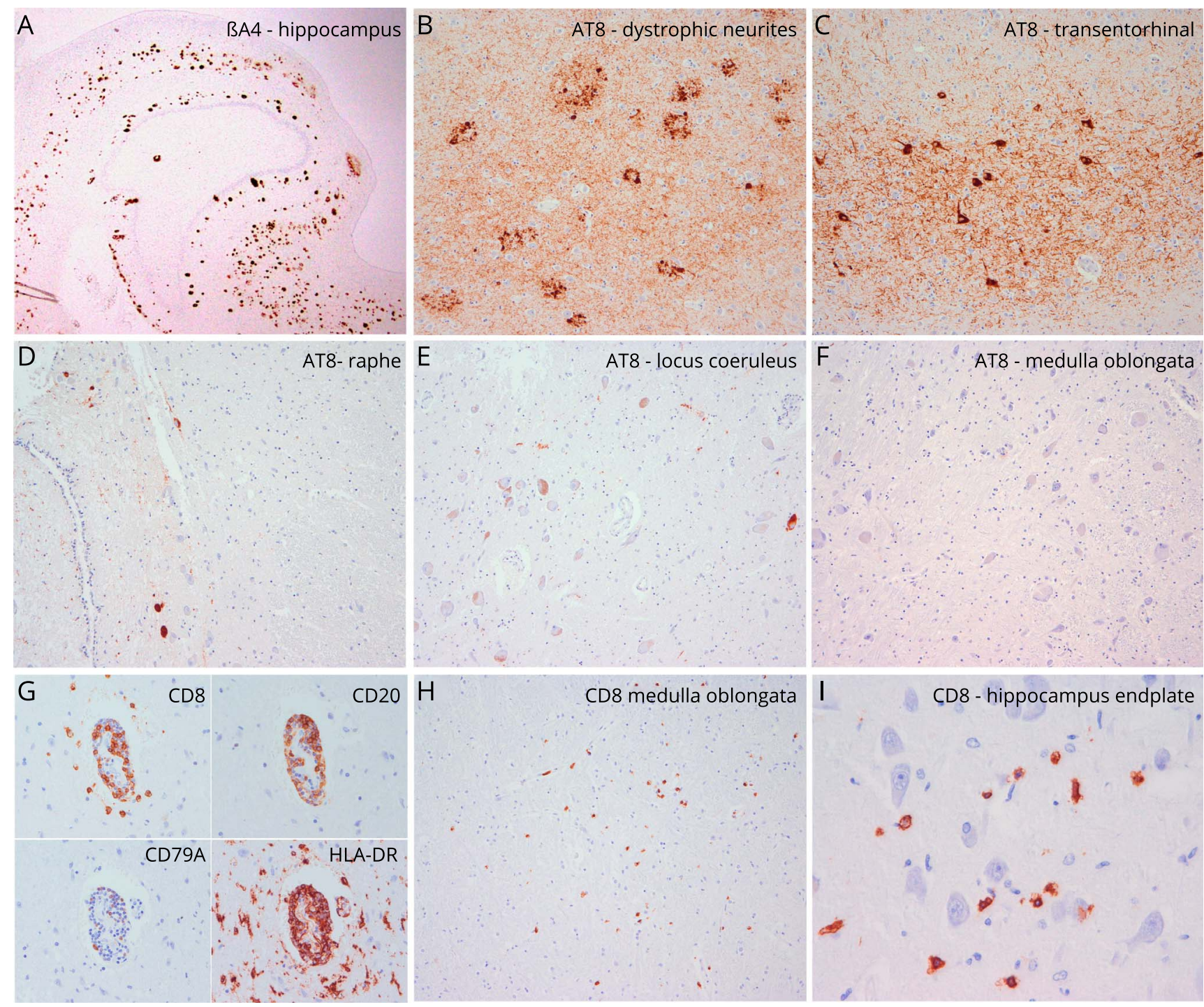

(A-F) Neurodegenerative changes are characterized by a moderate density of $\beta$ A4-amyloid plaques (A, magnification $\times 2$ ) associated with aggregates of phosphoTau. These are mainly observed in the hippocampus and are composed of dystrophic neurites related to neuritic plaques (B, magnification $\times 100)$, neurofibrillary tangles, and neuropil threads (C, magnification $\times 100)$. These changes are consistent with those observed in Alzheimer pathology. There are only isolated NFT in raphe $(D$, magnification $\times 100)$ and locus coeruleus $(E$, magnification $\times 100)$ and are absent in the medulla oblongata $(F$, magnification $\times 100)$. $(G-H)$ Mild inflammatory changes are detected in the hippocampus, hypothalamus, and brainstem. There are mild perivascular lymphocytic cuffs mainly composed of $\mathrm{CD}^{+} /$ $\mathrm{CD}^{+}$T-lymphocytes (G, magnification $\left.\times 200\right)$ and to a lesser extent of CD20 $\mathrm{B}$ cells. In some areas, particularly in the hypothalamus, brainstem $(\mathrm{H}$, magnification $\times 100)$, and hippocampus (I, magnification $\times 400), C D 8 . C D 8^{+}$lymphocytes infiltrate the brain parenchyma and have direct contact with individual neurons (I). 
Figure 2 Biochemical characterization of pTau in antiIgLON5 brains

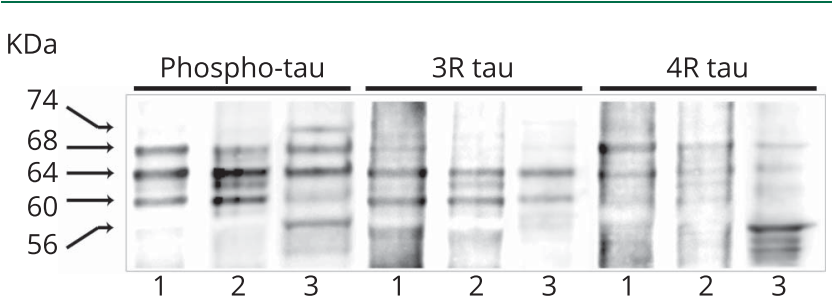

Immunoblot of insoluble tau aggregates extracted from (1) Alzheimer disease prefrontal cortex tissue, (2) hippocampus of the patient with antiIgLON5 described in the main text, and (3) brainstem of a previously described patient with anti-IgLON5 with the characteristic brainstem tauopathy. Note that the pattern of bands obtained with anti-phospho-tau antibodies clearly differentiates the 2 IgLON5 cases. In the patient with the brainstem pathology, the 74-KDa band is more intense and appears a differential band around $56 \mathrm{KDa}$ that immunoreacts with the 4R antibody. Both IgLON5 cases have 3R and 4R pTau isoforms. pTau = phosphorylated tau.

Absence of brainstem pTau pathology was also previously reported in the autopsy of a 69-year-old woman with IgLON5 antibodies. ${ }^{5}$ She had mild neuronal pTau pathology preferentially in temporomedial regions suggestive of primary agerelated tauopathy $(\mathrm{PART}){ }^{8}$ Similar to our case, CD4 and CD8 perivascular T-lymphocytes and few CD20 B-lymphocytes were found in the thalamus, basal ganglia, and mesencephalon. In addition, pTDP43 deposits in neurons and microglia were reported. In 2 other IgLON5 positive cases, neuropathologic reports were derived from brain biopsy. ${ }^{3,4}$ Perivascular $\mathrm{CD}^{+}$ T-lymphocytes and $\mathrm{CD}^{+} 8^{+}$and $\mathrm{CD} 163^{+}$microglia were observed but no pTau deposits. Although biopsies do not represent the whole pathologic picture, particularly the typical brainstem pathology, the reported findings suggest that early neuropathologic features of IgLON5 disease may include a variable inflammatory reaction, as we have also observed in the present case.

Although it remains speculative, as no supportive experimental data exist so far, a plausible explanation for the absence of $\mathrm{pTau}$ deposits in our patient with typical clinical, serologic, and HLA findings of anti-IgLON5 disease is that the immune-mediated mechanisms antedate the pTau pathology, which would represent a secondary event. ${ }^{9}$ It is not clear whether the mild inflammatory infiltrates represent an epiphenomenon, a perimortem phenomenon, or are even related to $\mathrm{AD}$ pathology.

Immunoblot studies of brain tissue accumulating insoluble Tau contribute to a further categorization of tauopathies, particularly the band pattern of pTau fragments might give better insight into the distribution of tau molecular species. ${ }^{7}$ Although we could study only 2 cases, our findings suggest that the antiIgLON5 brainstem tauopathy has a specific molecular signature and further confirms that this tauopathy is different from those previously characterized. ${ }^{7}$ In addition, the immunoblot study in the patient reported here emphasizes that pTau deposits restricted to the hippocampus/limbic regions of patients with anti-IgLON5 (e.g., as also reported in reference 5) may represent an age-related (PART or early $\mathrm{AD}$ ) comorbidity. ${ }^{8}$ The expanded spectrum of neurologic symptoms of anti-IgLON5 disease along with the absence of brainstem pTau pathology in this and other patients makes necessary to describe more cases to settle the frequency of tauopathy in this entity and the convenience of redefining the clinical and neuropathologic profiles, ${ }^{10}$ as it has been the case for other autoimmune encephalitis.

\section{Acknowledgment}

The authors thank Dr. Isidre Ferrer for his expert advice on Western blot studies of pTau protein.

\section{Study funding}

This study was supported in part by Fondo de Investigaciones Sanitarias, FEDER, Spain FIS 18/00067 (LS).

\section{Disclosure}

M.E. Erro, L. Sabater, L. Martínez, M. Herrera, A. Ostolaza. I. García de Gurtubay, and T. Tuñón report no disclosures. F. Graus receives royalties from Euroimmun for the use of IgLON5 as an autoantibody test and honoraria for Assistant Editor of MedLink Neurology. E. Gelpi reports no disclosures. Go to Neurology.org/NN for full disclosures.

\section{Publication history}

Received by Neurology: Neuroimmunology \& Neuroinflammation September 15, 2019. Accepted in final form November 7, 2019.

\section{Appendix Authors}

\begin{tabular}{|c|c|c|c|}
\hline Name & Location & Role & Contribution \\
\hline $\begin{array}{l}\text { Maria } \\
\text { Elena Erro, } \\
\text { MD, PhD }\end{array}$ & $\begin{array}{l}\text { Neurology } \\
\text { Department, } \\
\text { Complejo Hospitalario } \\
\text { de Navarra, IdiSNA, } \\
\text { Pamplona, Spain }\end{array}$ & Author & $\begin{array}{l}\text { Conception and design } \\
\text { of the study, data } \\
\text { analysis, and } \\
\text { manuscript drafting } \\
\text { for intellectual content }\end{array}$ \\
\hline $\begin{array}{l}\text { Lidia } \\
\text { Sabater, } \\
\text { MD, PhD }\end{array}$ & $\begin{array}{l}\text { Neuroimmunology } \\
\text { Program, IDIBAPS, } \\
\text { Barcelona, Spain }\end{array}$ & Author & $\begin{array}{l}\text { Analysis of pTau by } \\
\text { immunoblot and } \\
\text { revision of the } \\
\text { manuscript for } \\
\text { intellectual content }\end{array}$ \\
\hline $\begin{array}{l}\text { Laura } \\
\text { Martínez, } \\
\text { MD }\end{array}$ & $\begin{array}{l}\text { Neurology } \\
\text { Department, } \\
\text { Complejo Hospitalario } \\
\text { de Navarra, IdiSNA, } \\
\text { Pamplona, Spain }\end{array}$ & Author & $\begin{array}{l}\text { Acquisition of clinical } \\
\text { data, analysis and } \\
\text { interpretation of the } \\
\text { data, and revision of } \\
\text { the manuscript for } \\
\text { intellectual content }\end{array}$ \\
\hline $\begin{array}{l}\text { María } \\
\text { Herrera, } \\
\text { MD }\end{array}$ & $\begin{array}{l}\text { Neurology } \\
\text { Department, } \\
\text { Complejo Hospitalario } \\
\text { de Navarra, IdiSNA, } \\
\text { Pamplona, Spain }\end{array}$ & Author & $\begin{array}{l}\text { Acquisition of clinical } \\
\text { data, analysis and } \\
\text { interpretation of the } \\
\text { data, and revision of } \\
\text { the manuscript for } \\
\text { intellectual content }\end{array}$ \\
\hline $\begin{array}{l}\text { Aiora } \\
\text { Ostolaza, } \\
\text { MD }\end{array}$ & $\begin{array}{l}\text { Neurology } \\
\text { Department, } \\
\text { Complejo Hospitalario } \\
\text { de Navarra, IdiSNA, } \\
\text { Pamplona, Spain }\end{array}$ & Author & $\begin{array}{l}\text { Acquisition of clinical } \\
\text { data, analysis and } \\
\text { interpretation of the } \\
\text { data, and revision of } \\
\text { the manuscript for } \\
\text { intellectual content }\end{array}$ \\
\hline
\end{tabular}


Appendix (continued)

\begin{tabular}{|c|c|c|c|}
\hline Name & Location & Role & Contribution \\
\hline $\begin{array}{l}\text { Iñaki } \\
\text { García de } \\
\text { Gurtubay, } \\
\text { MD, PhD }\end{array}$ & $\begin{array}{l}\text { Neurophysiology } \\
\text { Department, } \\
\text { Complejo Hospitalario } \\
\text { de Navarra, } \\
\text { Pamplona, Spain }\end{array}$ & Author & $\begin{array}{l}\text { Acquisition of clinical } \\
\text { data, analysis and } \\
\text { interpretation of the } \\
\text { data, and revision of } \\
\text { the manuscript for } \\
\text { intellectual content }\end{array}$ \\
\hline $\begin{array}{l}\text { Teresa } \\
\text { Tuñón, } \\
\text { MD, PhD }\end{array}$ & $\begin{array}{l}\text { Brain Bank, } \\
\text { Navarrabiomed, } \\
\text { IdiSNA, Pamplona, } \\
\text { Spain }\end{array}$ & Author & $\begin{array}{l}\text { Neuropathologic } \\
\text { study, analysis and } \\
\text { interpretation of the } \\
\text { data, and revision of } \\
\text { the manuscript for } \\
\text { intellectual content }\end{array}$ \\
\hline $\begin{array}{l}\text { Francesc } \\
\text { Graus, } \\
\text { MD, PhD }\end{array}$ & $\begin{array}{l}\text { Neuroimmunology } \\
\text { Program, IDIBAPS, } \\
\text { Barcelona, Spain }\end{array}$ & Author & $\begin{array}{l}\text { Conception and design } \\
\text { of the study, data } \\
\text { analysis and } \\
\text { manuscript draft for } \\
\text { intellectual content }\end{array}$ \\
\hline $\begin{array}{l}\text { Ellen } \\
\text { Gelpi, MD, } \\
\text { PhD }\end{array}$ & $\begin{array}{l}\text { Institute of Neurology, } \\
\text { Medical University of } \\
\text { Vienna, Vienna, } \\
\text { Austria } \\
\text { Neurologic Tissue } \\
\text { Bank of the Hospital } \\
\text { Clinic-IDIBAPS } \\
\text { Biobank, Barcelona, } \\
\text { Spain }\end{array}$ & Author & $\begin{array}{l}\text { Neuropathologic } \\
\text { study, data analysis, } \\
\text { and manuscript } \\
\text { drafting for intellectual } \\
\text { content }\end{array}$ \\
\hline
\end{tabular}

\section{References}

1. Sabater L, Gaig C, Gelpi E, et al. A novel non-rapid-eye movement and rapid-eyemovement parasomnia with sleep breathing disorder associated with antibodies to IgLON5: a case series, characterisation of the antigen, and post-mortem study. Lancet Neurol 2014;13:575-586.

2. Gelpi E, Höftberger R, Graus F, et al. Neuropathological criteria of anti-IgLON5related tauopathy. Acta Neuropathol 2016;132:531-543.

3. Morales-Briceno $\mathrm{H}$, Cruse B, Fois AF, et al. IgLON5-mediated neurodegeneration is a differential diagnosis of CNS Whipple disease. Neurology 2018;90:1113-1115.

4. Montagna M, Amir R, De Volder I, Lammens M, Huyskens J, Willekens B. IgLON5associated encephalitis with atypical brain magnetic resonance imaging and cerebrospinal fluid changes. Front Neurol 2018;9:329.

5. Cagnin A, Mariotto S, Fiorini M, et al. Microglial and neuronal TDP-43 pathology in anti-IgLON5-related tauopathy. J Alzheimers Dis 2017;59:13-20.

6. Gaig C, Ercilla G, Daura X, et al. HLA and microtubule-associated protein tau H1 haplotype associations in anti-IgLON5 disease. Neurol Neuroimmunol Neuroinflamm 2019;6:e605. doi: 10.1212/NXI.0000000000000605.

7. Taniguchi-Watanabe S, Arai T, Kametani F, et al. Biochemical classification of tauopathies by immunoblot, protein sequence and mass spectrometric analyses of sarkosyl-insoluble and trypsin-resistant tau. Acta Neuropathol 2016;131:267-280.

8. Crary JF, Trojanowski JQ, Schneider JA, et al. Primary age-related tauopathy (PART): a common pathology associated with human aging. Acta Neuropathol 2014;128: 755-766.

9. Sabater L, Planagumà J, Dalmau J, Graus F. Cellular investigations with human antibodies associated with the anti-IgLON5 syndrome. J Neuroinflammation 2016; $13: 226$.

10. Gaig C, Compta Y. Neurological profiles beyond the sleep disorder in patients with anti-IgLON5 disease. Curr Opin Neurol 2019;32:493-499. 


\title{
Neurology \\ Neuroimmunology \& Neuroinflammation
}

\author{
Anti-IGLON5 disease: A new case without neuropathologic evidence of brainstem \\ tauopathy \\ Maria Elena Erro, Lidia Sabater, Laura Martínez, et al. \\ Neurol Neuroimmunol Neuroinflamm 2020;7; \\ DOI 10.1212/NXI.0000000000000651
}

This information is current as of December 11, 2019

\section{Updated Information \& \\ Services \\ References \\ Citations \\ Subspecialty Collections}

Permissions \& Licensing

Reprints including high resolution figures, can be found at:

http://nn.neurology.org/content/7/2/e651.full.html

This article cites 10 articles, 1 of which you can access for free at: http://nn.neurology.org/content/7/2/e651.full.html\#\#ref-list-1

This article has been cited by 1 HighWire-hosted articles: http://nn.neurology.org/content/7/2/e651.full.html\#\#otherarticles

This article, along with others on similar topics, appears in the following collection(s):

All Immunology

http://nn.neurology.org//cgi/collection/all_immunology

All Sleep Disorders

http://nn.neurology.org//cgi/collection/all_sleep_disorders

Myoclonus

http://nn.neurology.org//cgi/collection/myoclonus

Information about reproducing this article in parts (figures,tables) or in its entirety can be found online at:

http://nn.neurology.org/misc/about.xhtml\#permissions

Information about ordering reprints can be found online:

http://nn.neurology.org/misc/addir.xhtml\#reprintsus

Neurol Neuroimmunol Neuroinflamm is an official journal of the American Academy of Neurology.

Published since April 2014, it is an open-access, online-only, continuous publication journal. Copyright

Copyright (C) 2019 The Author(s). Published by Wolters Kluwer Health, Inc. on behalf of the American

Academy of Neurology.. All rights reserved. Online ISSN: 2332-7812.

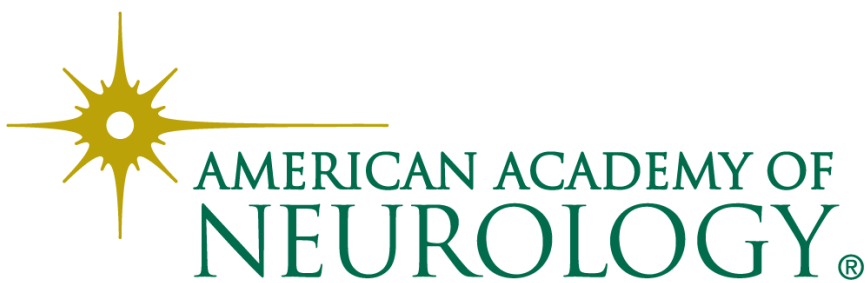

